\title{
Inés Rojkind
}

Doctora en Historia por El Colegio de México. Investigadora asistente, miembro de la Carrera del Investigador del CONICET, adscrita al Instituto de Historia Argentina y Americana "Dr. Emilio Ravignani”, FFyL-Universidad de Buenos Aires. Su área de investigación se centra en la historia política argentina y latinoamericana de fines del siglo XIX y principios del xx, especialmente en los temas de ciudadanía; formas de representación, participación e interlocución en el escenario político; la esfera pública y sus instituciones; relaciones entre sociedad civil y sociedad política; discursos e imaginarios políticos; construcción de identidades colectivas. Ha publicado: "Una explosión ruidosa de la indignación pública. Deuda, honor nacional y protesta política en Buenos Aires del novecientos" en Mirta Lobato (comp.) Buenos Aires. Manifestaciones, fiestas y rituales en el siglo XX, Biblos, Buenos Aires, 2011, pp. 27-41; "Orden, participación y conflictos. La política en Buenos Aires a fines del siglo XIX y comienzos del XX. Miradas clásicas y nuevas aproximaciones", Iberoamericana. América Latina-España-Portugal, núm. 34, junio de 2009, Madrid, pp. 154-159; "El malestar obrero. Visibilidad de la protesta social en Buenos Aires del novecientos", Travesía. Revista de Historia Económica y Social, núms. 10-11, 2008-2009, pp. 15-44, Universidad Nacional de Tucumán, San Miguel de Tucumán.

\section{Resumen}

Este trabajo analiza la relación entre la prensa, la oposición política y la movilización callejera en Buenos Aires a comienzos de 1900. Explora las formas y los sentidos de una dinámica contestataria del orden político que se gestó en esos años y que contribuyó a poner en cuestión la legitimidad del régimen conservador instaurado en 1880. Esa dinámica se nutría de las campañas que montaban los diarios y se expresaba bajo la forma de manifestaciones y protes- tas populares que incluían el uso de la violencia física y verbal. El propósito es contribuir a renovar la mirada sobre la política de ese periodo, contemplando no sólo la edificación desde arriba de un sistema político hegemónico, sino también las características de una vida política que se desenvolvía desde abajo mucho más vigorosa y variada que lo que las interpretaciones clásicas sugerían.

Palabras clave:

Régimen conservador, vida política, Buenos Aires, prensa, manifestaciones callejeras.

Fecha de recepción: Fecha de aceptación:

marzo de 2011 octubre de 2011 


\title{
"Street Government." Newspapers, Mobilizations and Politics in Buenos Aires in the 1900s
}

\author{
Inés Rojkind
}

Ph. D. in History from El Colegio de México. Assistant researcher, member of the CONICET Researchers' Career, affiliated to the "Dr. Emilio Ravignani” Institute of Argentinean and American History-University of Buenos Aires. Her area of research comprises Argentinean and Latin American Political History in the late 19th and early 20th century, particularly as regards civic issues; forms of representation, participation and dialogue in the political setting; the public sphere and its institutions; relations between civil society and political society; political discourse and imaginaries; construction of collective identities. Her publications include: "Una explosión ruidosa de la indignación pública. Deuda, honor nacional y protesta política en Buenos Aires del novecientos" in Mirta Lobato (comp.) Buenos Aires. Manifestaciones, fiestas y rituales en el siglo XX, Biblos, Buenos Aires, 2011, pp. 27-41; "Orden, participación y conflictos. La política en Buenos Aires a fines del siglo XIX y comienzos del xx. Miradas clásicas y nuevas aproximaciones”, Iberoamericana. América Latina-España-Portugal, no. 34, June, 2009, Madrid, pp. 154-159; "El malestar obrero. Visibilidad de la protesta social en Buenos Aires del novecientos", Travesía. Revista de Historia Económica y Social, no. 10-11, 2008-2009, pp. 15-44, Universidad Nacional de Tucumán, San Miguel de Tucumán.

\begin{abstract}
This study analyzes the link between the press, political opposition and street mobilization in Buenos Aires in the early 1900s. It explores the forms and meanings of a dynamic of political protest created during this period, which contributed to questioning the legitimacy of the conservative regime established in 1880 . This dynamic was based on the campaigns launched in the newspapers and was expressed

in the form of popular demonstrations and protests that included the use of physical and verbal violence. The aim is to provide a fresh perspective on the politics of the time, by analyzing not only the construction from the top of a hegemonic political system but also the characteristics of a political life that developed at the bottom in a far more vigorous, varied manner than classical interpretations suggested.
\end{abstract}

Key words:

Conservative regime, political life, Buenos Aires, press, street demonstrations.

Final submission: Acceptance:

March 2011 October 2011 


\title{
"El gobierno de la calle." Diarios, movilizaciones y política en el Buenos Aires del novecientos
}

\author{
Inés Rojkind*
}

$\mathrm{Q}$ uizá pueda parecer reiterativo comenzar señalando la renovación que ha experimentado en los últimos tiempos la historia política en América Latina, en general, y en Argentina, en particular. En efecto, se trata de un movimiento que lleva ya más de dos décadas de vigencia y que ha generado una importante transformación cuantitativa y cualitativa en el campo historiográfico. En el caso argentino, no obstante, esa transformación ha quedado restringida fundamentalmente a los trabajos sobre el siglo XIX, en especial el periodo anterior al corte trazado en $1880 .{ }^{1}$ En contraste, la época del llamado orden conservador (1880-1916) ha recibido una atención irregular. Se han realizado, es cierto, esfuerzos por revisar y discutir las interpretaciones prevalecientes acerca de los procesos políticos que se desenvolvieron en el transcurso de aquellos años, pero persisten sin desentrañar varios nudos problemáticos. En ese sentido, mi propuesta en este artículo consiste en repasar algunos de los aportes más relevantes que han traído consigo esos

* Quisiera agradecer la lectura y los comentarios que Hilda Sabato realizó a una primera versión de este texto, así como las críticas y sugerencias de los dictaminadores anónimos.

${ }^{1}$ Al respecto véase Sabato, "Política", 2007. esfuerzos de reconsideración de las visiones establecidas, así como las interrogantes que aún permanecen abiertas, para mostrar luego cómo se inserta en ese marco mi propia investigación acerca de la relación entre la prensa, la oposición política y la movilización callejera en la ciudad de Buenos Aires a comienzos del novecientos.

Sostengo que se gestó entonces, en particular durante la segunda presidencia de Julio A. Roca (1898-1904), una dinámica política contestataria que se nutría de escandalosas denuncias publicadas en los principales diarios de la ciudad y que se expresaba en las calles bajo la forma de ruidosas manifestaciones de protesta. En el contexto de un régimen político excluyente, que se basaba en la manipulación de los comicios y en el control de las candidaturas, el uso de la calle para expresar opiniones y articular reclamos se constituyó en una instancia fundamental de participación. Pero además, la protesta desplegada en las páginas de los diarios y en el espacio público urbano ayudó a poner en cuestión, desafiándolo, el concepto de orden que la elite gobernante pregonaba y defendía. Este trabajo explora las formas y los sentidos de esa dinámica opositora a través del análisis de algunos ejemplos concretos de movilizaciones que se efec- 
tuaron en Buenos Aires entre 1901 y 1903 , y que alcanzaron una gran repercusión entre los contemporáneos. La intención es contribuir a la proyección de una mirada sobre la política del periodo que contemple no sólo las disputas y alianzas en el interior de los grupos dirigentes, sino también las relaciones que se establecían entre la población y quienes gobernaban.

\section{GOBIERNOS ELECTORES, PARTICIPACIÓN POLÍTICA Y DESAFÍOS AL ORDEN}

Los trabajos más recientes no han producido, en realidad, una fractura profunda respecto de la versión que podríamos denominar clásica. Por eso, antes de considerar las reformulaciones que se han planteado últimamente se requiere volver sobre los argumentos centrales en torno a los cuales se estructura aquella mirada clásica que ha significado, a la vez, una referencia ineludible y un motivo de debate para ulteriores aproximaciones.

Esa mirada está fuertemente anclada en el análisis que Natalio Botana elaboró sobre el "régimen de hegemonía gubernamental" que los hombres del Partido Autonomista Nacional (PAN) establecieron desde su llegada al poder en $1880 .^{2}$ Este año inserta un corte sustancial en el relato historiográfico. Se sostiene que concluyó entonces, con la llegada de Julio A. Roca a la presidencia de la república, el trabajoso proceso de construcción de un orden político nacional y de afirmación del Estado central. Se afianzó una nueva elite política surgida de una serie de alianzas que se habían tejido entre las dirigen-

\footnotetext{
${ }^{2}$ Botana, Orden, 1994. El libro fue publicado por primera vez en 1977.
}

cias del interior del país y de las que participaban también algunos grupos porteños. El PAN fue creado formalmente en 1881 con la finalidad de consolidar aquel sistema de alianzas provinciales, pero no era, en rigor, un partido político en el sentido de una organización homogénea y disciplinada. Constituía, por el contrario, una coalición de agrupaciones o ligas que competían y negociaban entre sí. De ahí la importancia de los liderazgos como el que ejercía Roca para garantizar no sólo la unidad interna del partido sino también el predominio que el mismo acababa de conquistar a escala nacional. ${ }^{3}$

Dicho predominio descansaba, según ha mostrado Botana, sobre una serie de controles (los acuerdos entre grupos dirigentes, el reparto de cargos, la manipulación electoral) por medio de los cuales quienes habían accedido al poder en 1880 lograron conservarlo durante 36 años. Esos mecanismos operaban una "inversión del sistema representativo" en función de la cual los gobernantes se convertían en electores y producían votaciones en las que triunfaban los candidatos previamente convenidos. Dentro de ese esquema, la sucesión presidencial era una instancia clave pues se ponían en marcha entonces los dispositivos que obturaban la alternancia en el poder asegurando la reproducción de aquella forma de hegemonía gubernamental. El mandatario en funciones, imposibilitado por la Constitución de postularse para una reelección inmediata, aspiraba a controlar (o al menos influir sobre) la designación de su sucesor. La ciudadanía, por su parte, veía vulnerado el

\footnotetext{
3 Sobre la "naturaleza inorgánica" del PAN y la coexistencia en su interior de diversas ligas, véase Alonso, Jardines, 2010.
} 
derecho de designar a sus autoridades en comicios libres y transparentes. ${ }^{4}$

Evidentemente, no faltaron conflictos y sobresaltos que acompañaron (y en gran medida condicionaron) el funcionamiento concreto del régimen conservador. No sólo emergieron resistencias que tomaron incluso el carácter de fallidos alzamientos revolucionarios. El partido gobernante se hallaba asimismo atravesado por tensiones y disputas internas que tendían a debilitarlo frente a los eventuales desafíos. La literatura especializada no ha dejado de señalar, por supuesto, la significación de las contradicciones que en diversos momentos sacudieron la hegemonía del PAN. Sin embargo, el eje de la mirada historiográfica no ha estado puesto allí, sino en la comprensión de los mecanismos que le permitieron al régimen neutralizar los desafíos y prolongar su existencia hasta bien entrado el siglo Xx. Desde ese punto de vista, lo que se ha buscado resaltar es que el sistema de dominación política montado por el PAN no se derrumbó ni fue derrocado por la fuerza. Se subraya, en cambio, el hecho de que la transformación que condujo finalmente al ocaso del régimen se desenvolvió desde adentro y de manera gradual, empujada ante todo por una corriente reformista cuyo objetivo era depurarlo de los rasgos más controvertidos y excluyentes. En 1912 fue aprobada una nueva ley electoral con esa finalidad. Sus efectos resultaron ser, no obstante, mucho

\footnotetext{
${ }^{4}$ Botana, Orden, 1994. Respecto del ejercicio de los derechos políticos, conviene recordar que si bien no existían requisitos formales en términos de educación o ingresos, en la práctica el acto de votar era un modo de intervención en general limitado a los ciudadanos reclutados y movilizados por las maquinarias electorales.
}

más drásticos. Cuatro años después, en los primeros comicios presidenciales que se realizaron estando en vigor la nueva normativa, se impuso el candidato de la opositora Unión Cívica Radical (UCR) y el PAN perdió la supremacía que había detentado a lo largo de casi cuatro décadas. ${ }^{5}$

Si bien la relevancia de este enfoque es innegable y, como se indicó, constituye el marco de referencia obligado para pensar la política del periodo, inevitablemente han surgido (y continúan apareciendo) interrogantes y problemas que exceden los contornos de esa visión y que requieren, por consiguiente, de otro tipo de abordajes. Las líneas alternativas de investigación que se han abierto ofrecen indicios a partir de los cuales componer una imagen distinta, más matizada y en determinados sentidos más compleja, de los procesos políticos que tuvieron lugar en el lapso de aquellos años. Las preguntas que se formulan en esa dirección atañen tanto a las formas de acción y movilización colectivas de la población como a los mecanismos de interlocución entre gobernantes y gobernados. Se han comenzado a rastrear las imbricaciones entre, por un lado, el proceso de edificación desde arriba de un orden político hegemónico y, por el otro, las formas y los sentidos de una vida política que se desenvolvía desde abajo mucho más vigorosa y variada que lo que las interpretaciones clásicas permitían suponer. ${ }^{6}$

\footnotetext{
${ }^{5}$ Ibid., pp. 217 y ss. Con variaciones, otros trabajos comparten un enfoque similar: Gallo, "Roquismo”, 1975, y también, "Consolidación”, 2000; Cortés, "Auge”, 1995, pp. 224-233; Peck, "Presidencias", 1980; Botana, "Arco", 2005, y Rock, Construcción, 2006, pp. 277-322.

${ }^{6}$ Esas líneas alternativas de interpretación encontraron un estímulo fundamental en los trabajos de
} 
Esas interrogantes han inspirado una serie de trabajos que, especialmente respecto del caso de la ciudad de Buenos Aires a fines del siglo XIX y principios del $\mathrm{XX}$, permiten entrever la existencia de una vida política activa que trascendía los límites de la dinámica interna del régimen conservador. De hecho, y como bien observa Paula Alonso, el reto ha pasado a ser el de explicar cómo pudo desarrollarse una "incipiente cultura de la participación" en el marco de los controles que fijaban los gobiernos del PAN y teniendo en cuenta, además, la inquietud con que estos contemplaban cualquier signo de inestabilidad política. ${ }^{7}$ En efecto, los hombres del régimen conservador le otorgaban una gran importancia a la preservación del orden público, considerado uno de los pilares sobre los cuales edificar una sociedad próspera y moderna, un sistema político estable y un Estado eficiente. Según esa concepción, la actividad política era intrínsecamente disruptiva y correspondía, en consecuencia, reducir su ejercicio a la búsqueda pragmática de consensos y a la aceptación del gobierno de las instituciones. En teoría, no había espacio en tal esquema para la agitación electoral, las

Hilda Sabato sobre las formas de participación política popular en Buenos Aires antes de 1880. Véase Sabato, Política, 1998. Desde una perspectiva más amplia, es posible emparentarlas con desarrollos presentes en investigaciones referidas a otros espacios latinoamericanos. Pueden mencionarse los siguientes ejemplos: Carvalho, Bestializados, 1989, y Pamplona, Riots, 1996; las contribuciones reunidas en Arrom y Ortoll, Riots, 1996; en Connaughton, Poder, 2003, y en Ronzón y Valdéz, Formas, 2005. Otro ejemplo reciente, y desde preocupaciones algo diferentes pero igualmente interesantes, es el de Gutiérrez, Mundo, en prensa.

7 Alonso, "Reciente", 1998, p. 411. manifestaciones callejeras ni la violencia armada, prácticas en relación con las cuales la población porteña poseía una arraigada tradición. $^{8}$

Durante algunos años la vida política en la ciudad de Buenos Aires pareció ajustarse a aquellos parámetros, pero la situación se reveló pronto bastante más complicada. En el año 1890 se combinaron los efectos de una devastadora crisis económica con el estallido de un alzamiento armado que la oposición organizó con el objetivo de derrocar al entonces presidente Miguel Juárez Celman (había sucedido a Roca en 1886). La rebelión fracasó, fue derrotada, pero entre tanto se había hecho realidad uno de los peores fantasmas que inquietaban a los hombres del PAN: el fantasma de la violencia política invadiendo las calles de la capital del país. Por otro lado, es cada vez más claro que a través de múltiples cauces las voces contrarias al régimen hallaron la manera de expresarse. Diversos estudios evidencian, por ejemplo, que a pesar de las manipulaciones la instancia electoral implicaba un grado de movilización política considerable que podía incrementarse en determinadas coyunturas. Por su parte, los diarios (y la prensa en general) funcionaban como canales a través de los cuales la discusión política podía extenderse más allá del estrecho círculo que conformaban sus protagonistas habituales. El periodismo se modernizaba aceleradamente, pero no por eso se desprendía de la capacidad de moldear a la opinión pública e instigarla a la acción.? La ocupación del espacio público,

\footnotetext{
${ }^{8}$ Alonso, "Primavera", 1997. Sobre las tradiciones políticas porteñas, véase Sabato, "Pueblo", 2009.

9 Acerca de todas estas cuestiones, véanse, entre otros, Alonso, Jardines, 2010, pp. 45-55, "Primavera",
} 
en tanto, continuaba siendo como en el periodo anterior a 1880 una práctica a la que la población acudía con frecuencia, pero las manifestaciones revestían nuevas modalidades asociadas con el carácter contestatario que solían exhibir frente a los gobernantes y en relación con el orden político imperante. ${ }^{10}$

Se requiere, entonces, continuar avanzando en el análisis de estos y otros aspectos para delinear un cuadro más preciso de las características de la vida política en Buenos Aires durante los años del régimen conservador. Por otro lado, pero en relación con ello, se plantea un segundo problema ligado con la posibilidad de trascender las fronteras de la explicación clásica y adentrarse en zonas hasta ahora insuficientemente examinadas. Aquella explicación privilegia -como ya se ha indicado- el análisis de los orígenes del régimen político instaurado en 1880 , su consolidación y la paulatina transformación que experimentó desde adentro, a medida que se hizo necesario encontrar nuevas justificaciones para el mantenimiento de su preeminencia. La imagen resultante tiende a revelarnos un sistema de poder resistente que mantenía a la opo-

1997, y Revolución, 2000, pp. 198-230; Zimmermann, "Prensa", 1998; Cibotti, "Sufragio", 1995, y Yablon, "Patronage", 2003, especialmente los capítulos 4 y 7 .

${ }^{10}$ Los estudios sobre manifestaciones y otras formas de uso político de las calles en Buenos Aires a comienzos del siglo XX son todavía escasos. Este artículo y la investigación que lo sustenta están enfocados a profundizar en el estudio de esa temática que ha permanecido poco explorada en comparación, por ejemplo, con la atención que sí ha recibido para ese mismo periodo la expresión pública de la conflictividad social y obrera. Hay excepciones sin embargo. Por ejemplo, Tato, "Contienda", 2010. sición marginada y que conseguía reproducirse gestionando con éxito las tensiones internas que lo atravesaban. El problema es que dentro de ese marco no hay sino un margen muy limitado para interrogarse acerca de los desafíos y las objeciones que se levantaron contra el dominio del Pan y contra lo que, según denunciaba insistentemente la prédica opositora, ese dominio implicaba: el avasallamiento de la soberanía popular, la degradación de las tradiciones políticas, el desquiciamiento de las instituciones, el enervamiento cívico, etc. Si bien es verdad que luego del fracaso del llamado ciclo revolucionario del noventa no se verificaron desafíos de una magnitud similar, también lo es que sólo retrospectivamente podemos saber que el sistema que aseguraba el monopolio del poder en manos del PAN perduró hasta la derrota sufrida en las elecciones presidenciales de 1916. Si se suspende, en cambio, tal mirada retrospectiva se alcanzan a percibir las perturbaciones que, aun cuando no provocaron el descalabro del orden impuesto, fueron sin embargo resquebrajando su legitimidad y alimentando con ello los conflictos y los dilemas que inquietaban a la elite gobernante.

\section{LA SEgUNDA PRESIDENCIA DE Roca. CAMPAÑAS PERIODÍSTICAS Y PROTESTAS CALLEJERAS}

En relación con algunas de esas perturbaciones, precisamente, trata la investigación que realicé sobre el despliegue en la ciudad del novecientos de una dinámica contestataria que buena parte de la prensa porteña promovía a través de campañas de denuncias y de exhortaciones a que la 
protesta ganara las calles. El destinatario principal de esas campañas era Julio A. Roca, quien desde 1898 ejercía nuevamente el gobierno del país. Roca había obtenido una victoria canónica en las elecciones de aquel año y su regreso a la presidencia fue celebrado por amigos y partidarios como la vuelta del "piloto experimentado" que habría de consolidar la paz recobrada "tras los rudos sacudimientos". Posteriormente, también la historiografía ha tendido a ver en las circunstancias que rodearon a la reelección de Roca la confirmación de que se habían agotado los impulsos disruptivos desatados en 1890 y de que el orden había sido por fin reinstaurado. ${ }^{11}$

En efecto, todo hacía presumir que el régimen emergía robustecido en aquella coyuntura. La revolución del Noventa, aunque frustrada, había inaugurado un periodo de gran inestabilidad política que incluyó movilizaciones callejeras, protestas populares y nuevas rebeliones armadas en varias provincias. Hacia 1898, no obstante, el ciclo de protestas parecía haberse agotado. Los últimos levantamientos habían sido reprimidos y la UCR (la agrupación que los había liderado) se hallaba profundamente desgastada por los fracasos. Por su parte, y en contraste, el PAN se presentaba unido y fortalecido alrededor del retorno de Roca. Para el lanzamiento de su candidatura presidencial Roca había contado con el apoyo de otro dirigente destacado del partido, el senador Carlos Pellegrini. El respaldo de Pellegrini sirvió para aglutinar las filas oficialistas detrás de la postulación de Roca y

${ }^{11}$ Tribuna, 13 de octubre de 1898. Botana, "Arco", 2005, p. 125; también Gallo, Carlos, 1997, p. 64. vino a ratificar, aparentemente, la vigencia de una ventajosa sociedad política que poseían ambos líderes del PAN. ${ }^{12}$ En realidad, como veremos en seguida, las contradicciones que surcaban esa alianza no iban a tardar en manifestarse. Por el momento, no obstante, la unidad del partido parecía resguardada y esa circunstancia lo fortalecía también hacia afuera. En más de un sentido, por lo tanto, la atmósfera que hacia fines de la década de 1890 rodeaba la vuelta de Roca a la presidencia se vislumbraba favorable al oficialismo. Lo interesante es comprobar, sin embargo, que justamente en ese contexto se gestó en Buenos Aires un movimiento opositor que, aunque no tomó la forma de nuevos intentos revolucionarios, convirtió a Roca, el presidente de la república y la figura más emblemática del régimen, en "el odiado de la calle, el acusado de todos los diarios". ${ }^{13}$

Tal como ya se dijo, esa dinámica se nutría de los reiterados ataques que los diarios más importantes de la ciudad publicaban objetando las decisiones y los actos gubernamentales, y se fundaba igualmente en los llamamientos de la prensa para que "constara en las calles públicas" la indignación general que el proceder de las autoridades supuestamente provocaba. El periodismo porteño experimentaba en esos años del cambio de siglo un espectacular crecimiento. Buenos Aires poseía a fines del XIX "a nivel mundial, una de las mayores circulaciones de periódicos por habitante”, y la expansión del mundo

${ }^{12}$ Gallo, Carlos, 1997, p. 64. Pellegrini era una figura preponderante dentro y fuera del PAN. Desde el Senado, donde ocupaba una banca, influía decisivamente en la política del régimen.

${ }^{13}$ Vedia, Como, 1954. 
periodístico continuaba hacia principios del novecientos. ${ }^{14}$ En ese contexto, en la mayoría de los diarios -empezando por los dos matutinos más influyentes y de mayor tiraje, La Prensa y La Nación- se revelaba fuertemente la crítica de los gobiernos del PAN y, en particular, hostil al roquismo. La Nación actuaba como portavoz de un sector político, el mitrismo, que objetaba los métodos del grupo gobernante para mantenerse en el poder y que reivindicaba la libertad de sufragio. Era un "periódico híbrido", como lo ha calificado Julio Ramos, que sin abandonar su condición de instrumento partidario procuraba incorporar nuevas funciones informativas, comerciales y hasta literarias. ${ }^{15}$ En cuanto a La Prensa, su condición de órgano independiente (en el sentido de "no partidario") no lo inhibía de expresar claramente sus prefe-

${ }^{14}$ Alonso, Jardines, 2010, p. 47; también Saítta, Regueros, 1998, pp. 32 y 33. Las cifras son elocuentes: en 1885 se imprimían 25 diarios que, resalta Alonso, sumaban una circulación total de 17000 ejemplares por día, lo cual a su vez representa un promedio de 23 ejemplares por cada 100 habitantes. Treinta años después, el total del material impreso en la ciudad era, según muestra Saítta, de aproximadamente 520000 ejemplares diarios. Ese crecimiento se apoyaba en varios factores, entre ellos, el aumento de los niveles de alfabetización junto con la consiguiente ampliación del potencial público lector.

${ }^{15}$ Ramos, Desencuentros, 2003, p. 100. El mitrismo (por Bartolomé Mitre) había tenido gran influencia en el escenario político durante las décadas de 1860 y 1870 . Desde la llegada del PAN al poder en 1880, los mitristas habían oscilado entre la impugnación y el acuerdo con el régimen. Hacia comienzos del novecientos, sin embargo, reorganizados bajo el nombre de Partido Republicano, buscaron adoptar una actitud inequívocamente opositora que se vio reflejada en las páginas de La Nación. Zimmermann, "Prensa", 1998. rencias políticas ni de intervenir con una posición tomada en los debates de actualidad. Y esa posición estaba frecuentemente impregnada de un implacable antirroquismo que el diario no se cuida de ocultar, todo lo contrario. Pero además La Prensa era el órgano que lideraba el proceso de modernización periodística en Buenos Aires y en el país. Poseía el mejor servicio telegráfico, tenía corresponsales en las provincias y en el extranjero, proporcionaba una amplia gama de noticias y servicios al público lector, operaba como una verdadera empresa comercial y había incorporado notables adelantos técnicos que le permitían lanzar grandes tiradas. ${ }^{16}$

Estos dos diarios, especialmente $\mathrm{La}$ Prensa, eran los que con sus editoriales y notas fijaban tanto los contenidos como la intensidad de la propaganda opositora en la que se enrolaban también otros periódicos de menor circulación pero asimismo relevantes, como El Tiempo y el vespertino El Diario. ${ }^{17}$ Esa propaganda opositora adquiría, por otra parte, un relieve excepcional en el contexto de un

${ }^{16}$ En 1896 el tiraje del diario era de 58000 ejemplares, y en 1913 había ascendido a 160000 ejemplares, una parte de los cuales se distribuía en el interior del país. Saítta, Regueros, 1998, pp. 29-31. La Prensa era propiedad de los Paz, una de las familias más tradicionales e importantes de Buenos Aires. Si bien no se privaba de articular un discurso político ni de expresar sus opiniones, el lema del diario era el de ser portavoz de la "opinión pública" por encima de cualquier causa partidaria.

${ }^{17}$ El Diario había surgido a comienzos de la década de 1880 como el vocero de un sector rival de Roca dentro del PAN. El Tiempo, en tanto, no disimulaba sus simpatías por la causa revolucionaria del noventa ni se abstenía de emplear un tono mordaz para criticar al gobierno. Marco, Historia, 2006, pp. 391 y 392, y Yablon, "Patronage", 2003, p. 197. 
escenario político que aparecía dominado por el PAN y en ausencia de otras voces contrarias de peso. Las críticas periodísticas abarcaban desde la gestión "desastrosa" de las finanzas públicas hasta el manejo "deshonroso" de las relaciones exteriores; desde los "atropellos" contra el sufragio hasta el "abandono" en que se encontraban los sectores sociales más desprotegidos. No faltaban tampoco las insinuaciones sobre "negociados" o acuerdos oscuros en los que se privilegiaban intereses particulares por encima del bienestar general. Pero la intervención de la prensa no terminaba allí. Las publicaciones participaban también en la creación y la movilización de la misma "opinión pública" cuyos intereses decían representar. Aseguraban al respecto que en el contexto de un sistema electoral viciado la posibilidad de hacerse ver y escuchar en las calles constituía un derecho al que el pueblo soberano no podía renunciar.

En consonancia con esa prédica, las campañas promovidas por los periódicos cristalizaron en más de una ocasión bajo la forma de mítines y movilizaciones callejeras, que se destacaban por la agresividad verbal y muchas veces también física que desplegaban los manifestantes. Los estudiantes universitarios, en particular, se mostraban por demás proclives a arrogarse la misión de traducir al lenguaje de la acción las acusaciones que publicaban los diarios. La vinculación de los estudiantes con la política no era nueva. En el año 1890, sin ir más lejos, la Unión Cívica de la Juventud, una agrupación universitaria creada con el objetivo de combatir la desmovilización política imperante, había contribuido decisivamente a activar el movimiento de impugnación del régimen que luego desembocó en el levantamiento armado al cual ya hemos hecho referencia. En la ciudad del novecientos el recuerdo de aquella experiencia continuaba gravitando. Pero además, acompañando una militancia universitaria que por esa misma época cobraba cada vez más fuerza, los estudiantes asumieron en la escena política un protagonismo impensado y sus acciones se constituyeron en "un elemento de presión antes desconocido". ${ }^{18} \mathrm{~A}$ continuación se analizan algunos ejemplos de circunstancias en las que esa presión se hizo sentir efectivamente, alimentada por las denuncias de la prensa y por las incitaciones más o menos abiertas a que las "iras de la opinión" se exteriorizaran en las calles.

\section{"GRANDES EXPLOSIONES POPULARES QUE CAUSAN ESCARMIENTO”}

\section{El repudio contra la unificación de la deuda externa}

A principios del mes de julio de 1901 se produjo en Buenos Aires una violenta protesta popular que se prolongó varios días y que llevó a la declaración del estado de sitio. Los hechos se desencadenaron a partir del repudio causado por una iniciativa que impulsaba el gobierno de Roca para la renegociación de la deuda externa y que, según las acusaciones del periodismo, dañaba seriamente el honor y la soberanía nacionales. El llamado plan de unificación de la deuda preveía canjear las diversas emisiones de empréstitos que circulaban entonces por un nuevo y único título con plazos y condiciones supuestamente favorables para la Argentina. El objetivo era

${ }^{18}$ Halperín, Historia, 1962, p. 110. 
aliviar la carga que para el presupuesto nacional representaban los servicios de la deuda externa. En razón de la buena reputación que poseía en los círculos financieros europeos, Carlos Pellegrini fue el encargado de llevar adelante las negociaciones con los acreedores extranjeros, en su mayoría ingleses. Para lograr el consentimiento de estos últimos se incluyó en el acuerdo una cláusula de garantía según la cual los nuevos papeles serían respaldados con rentas de Aduana. ${ }^{19}$

En cuanto arribaron a Buenos Aires las primeras noticias acerca del contrato firmado en Londres se desató en los diarios una virulenta campaña contra "el affaire de la unificación", como lo denominó $L a$ Prensa. Se decía que los inconvenientes financieros tenían su origen en las falencias de una "administración desordenada" y, sobre todo, en el esfuerzo que demandaba sostener los "presupuestos oligárquicos" de los gobiernos del PAN. Se acusaba a Roca y a Pellegrini de haber llevado adelante "negociaciones clandestinas" con los acreedores para suscribir un arreglo que significaba una "lápida colocada sobre los despojos del crédito argentino". ${ }^{20}$ Pero el punto verdaderamente controvertido, aquel alrededor del cual se articularon las críticas más furiosas, era el tema de la garantía ofrecida a los acreedores. Según

${ }^{19}$ El monto de la deuda externa argentina había crecido de manera exorbitante durante el gobierno de Juárez Celman (1886-1890). El estallido de la crisis económica en 1890 había obligado a suspender los pagos, pero luego se acordó con los acreedores una prórroga hasta fines de esa década. Sobre la tramitación del plan de unificación, véaser Gerchunoff, Rocchi y Rossi, Desorden, 2008, pp. 281-283.

${ }^{20}$ Por ejemplo, La Prensa, 9 de junio de 1901; La Nación, 12 de junio de 1901; El Diario, 13 de junio de 1901; El Tiempo, 2 de julio de 1901.
La Nación, la disposición dañaba la reputación internacional del país colocándolo "al nivel de esas factorías confiscadas por una compañía de prestamistas y sometidas a ella por un protectorado". En realidad, la práctica de otorgar garantías especiales no era un procedimiento inusual, pero adquirió connotaciones inesperadas en el clima de exaltación nacionalista creado por la aparente inminencia de un conflicto bélico con Chile. Había recrudecido en los últimos meses la disputa limítrofe que mantenían ambos países y, en ese contexto, los diarios sostenían que la cláusula de garantía entrañaba un peligro para la soberanía nacional porque depositaba en manos de un "sindicato de banqueros extranjeros" la facultad de disponer de recursos que podían ser esenciales en el caso de una guerra. La Prensa, en particular, esgrimió ese argumento con el objetivo de fomentar el rechazo contra la unificación de la deuda. Fue incluso más allá, y sugirió la conveniencia de que "el desagrado unánime producido por el concordato financiero" tomara la forma de "una explosión ruidosa de la indignación pública". ${ }^{21}$

Y, efectivamente, la protesta no tardó en trasladarse a las calles. Los estudiantes universitarios fueron quienes tomaron la iniciativa, en particular los de la Facultad de Derecho. La Universidad de Buenos Aires atravesaba entonces algunas transformaciones que, con el correr de los años, se iban a revelar significativas. La educación superior comenzaba a funcionar, aunque de manera todavía muy incipiente, como una vía de integración y de ascenso social en el marco de una socie-

${ }^{21}$ La Prensa, 9 de junio de 1901; La Nación, 12 de junio de 1901. 
dad, como era la porteña, que estaba siendo profundamente renovada por el fenómeno de la inmigración masiva. La Facultad de Derecho, que tradicionalmente había sido el ámbito de formación de la elite política y social, no permanecía ajena a tales cambios. Los alumnos de esa casa de estudios empezaron a organizarse para formular diversos reclamos y demostraron una notable capacidad de movilizarse y de presionar para lograr que sus reivindicaciones fueran atendidas. ${ }^{22} \mathrm{Y}$ en ese marco desempeñaron también un papel central en las protestas que, en más de una oportunidad, se efectuaron contra las decisiones y el estilo político del presidente Roca.

En julio de 1901, como decíamos, los estudiantes se pusieron al frente del movimiento en rechazo de la unificación de la deuda externa. Se realizaron en la Facultad de Derecho varias asambleas (con la presencia también de algunos representantes de las facultades de Medicina e Ingeniería) en las que se diseñó un plan de acción. Se resolvió convocar a un mitin en la Plaza de Mayo para reclamar al Congreso que rechazara el proyecto de renegociación y unificación de la deuda que impulsaba el poder ejecutivo. Los jóvenes citaban las "revelaciones" hechas por el periodismo y

${ }^{22}$ Las demandas se vinculaban con cuestiones puntuales, pero comprendían también críticas más abarcadoras referidas al contenido demasiado "profesionalista" de los planes de estudio o al carácter "oligárquico" de las estructuras de gobierno universitario. Para canalizar esos reclamos los estudiantes implementaron diversas estrategias, entre ellas las huelgas que -como ocurrió en Derecho, en 1903-1904, y en Medicina, en 1905- podían llegar a paralizar las clases y que derivaron a veces en episodios de confrontación violenta. Halperín, Historia, 1962, pp. 109-121; Buchbinder, Historia, 2005, pp. 76 y 77. cuestionaban las "cláusulas humillantes" que, afirmaban, contenía el acuerdo financiero. ${ }^{23} \mathrm{El}$ mitin se realizó el miércoles 3 de julio sin que se produjeran incidentes. Pero en cuanto concluyó el acto, "un grupo numeroso de estudiantes, reforzado por otro no menos numeroso de pueblo", se apresuró a organizar una nueva movilización. Los manifestantes atacaron las imprentas de Tribuna y El País, voceros del roquismo y del pellegrinismo, respectivamente. Estos dos órganos se habían adjudicado la misión de defender el proyecto financiero desestimando las críticas que le hacían los diarios opositores. La multitud arremetió en su contra con piedras y palos, entre insultos a la "prensa claudicadora”. Se registraron, incluso, algunos disparos contra la fachada del edificio de El País, en la calle Florida. Esa misma tarde, "grupos hostiles" agredieron también las casas particulares del presidente Roca y de Pellegrini. Rompieron vidrios y provocaron numerosos "destrozos". Tuvo que intervenir la guardia presidencial, pero los tumultos se extendieron hasta la madrugada. La policía recorría las calles del centro de la ciudad dispersando a los manifestantes que daban vivas a la juventud y a la prensa independiente, y que exigían “a grandes voces" la renuncia de Roca. ${ }^{24}$

${ }^{23}$ Los jóvenes firmaron una solicitud que apareció reproducida en los principales diarios. Por ejemplo, La Prensa, 1 de julio de 1901, p. 3. El Congreso debía aprobar el convenio para darle validez legal. El Senado le otorgó media sanción el 18 de junio y, a continuación, se anunciaba su tratamiento de la Cámara de Diputados. La sesión, sin embargo, no pudo efectuarse porque antes estalló la protesta en las calles.

${ }^{24}$ La geografía de las manifestaciones se concentró en el centro político de la ciudad: la zona de la Plaza de Mayo y sus alrededores. Para la crónica de los 
Al día siguiente, la tensión se incrementó. Las redacciones de La Prensa, La Nación y otros diarios "independientes" se vieron invadidas por el público que deseaba enterarse de las últimas novedades. "Grupos de 20 y 30 personas" formaban "columnas numerosas que prorrumpían en gritos de ¡abajo la unificación!” Pasado el mediodía, una multitud "compuesta en su mayoría de jóvenes, muchos de ellos universitarios", se congregó nuevamente en la Plaza de Mayo. Al parecer, los manifestantes intentaron esta vez traspasar las vallas de seguridad que rodeaban la casa de gobierno. La policía reaccionó y durante los choques que se produjeron entonces fue herido mortalmente un agente, alcanzado por un disparo. La represión se endureció a partir de aquel momento. "Subiendo con sus caballos sobre las veredas y parques", los vigilantes obligaron al "numeroso pueblo, que se calcula en más de 2000 personas, a abandonar aquel sitio". Las crónicas describen escenas caóticas: manifestantes que escapaban de la policía, coches y tranvías atascados en medio de las corridas, y transeúntes que huían despavoridos. ${ }^{25}$ Llegado ese punto,

eventos del 3 de julio, véase El Diario y El Tiempo, 3 de julio de 1901; La Prensa, La Nación, Tribuna y El País, 4 de julio de 1901; Caras y Caretas, 6 de julio de 1901. El jefe de policía de la ciudad preparó un informe que fue leído en el Congreso. Véase Diario de Sesiones de la Cámara de Senadores (en adelante DSCS), 4 de julio de 1901, p. 110.

${ }^{25}$ El Tiempo, 4 de julio de 1901; La Nación y El País, 5 de julio de 1901; La Prensa, 31 de julio de 1901; Caras y Caretas, 13 de julio de 1901. La prensa inglesa en Buenos Aires hizo asimismo su relato de los hechos: The Buenos Aires Herald, 4 de julio de 1901; The Review of the River Plate, 6 de julio de 1901. Información adicional se puede encontrar en el Archivo Policial (en adelante AP), Copiadores de notas (en ade- la situación había tomado características que las autoridades no estaban dispuestas a tolerar. El presidente Roca envió al Congreso un mensaje solicitando autorización para declarar el estado de sitio en la capital. Existía, argumentaba, un "estado de conmoción interna” que impedía el normal ejercicio de la autoridad y amenazaba los intereses fundamentales de la sociedad. El mensaje mezclaba las referencias a agitadores profesionales y a "elementos mal avenidos con el orden social”, con el recuerdo de la revolución del Noventa y la predicción de "explosiones más peligrosas aún" que estaban, presuntamente, próximas a estallar. El estado de sitio fue aprobado en la madrugada del viernes 5 de julio. Quedaban prohibidas las reuniones públicas y los diarios debían abstenerse de publicar comentarios que pudieran ser interpretados como una provocación. Los disturbios y la represión policial habían dejado numerosos detenidos, varios heridos e incluso algunas víctimas fatales. ${ }^{26}$

lante $\mathrm{CN}$ ), sección $2^{\mathrm{a}}$, libro 67,6 de julio de 1901, fs. 419-420; sección 1a libro 121, 8 de julio de 1901, fs. 438-439. También en el informe del encargado de la legación estadunidense en Buenos Aires, William P. Lord. Véase Lord al secretario de Estado John M. Jay, Buenos Aires, 11 de julio de 1901, en Universidad Torcuato Di Tella (UTDT), Microcopies of Records in the Nacional Archive 69 (MRNA), rollo 35, vol. 40, diciembre 5 de 1900-julio 15 de 1902, p. 128.

${ }^{26}$ Véase Boletín Oficial de la República Argentina (BORA), 5 de julio de 1901; DSCS, 4 de julio de 1901, pp. 107-111; Diario de Sesiones de la Cámara de Diputados (en adelante DSCD), 4 de julio de 1901, pp. 266-285. La información sobre detenidos, heridos y muertos es muy fragmentaria, y no permite reconstruir el perfil social de las víctimas. Las crónicas señalan la presencia de "otros elementos" que se sumaron a la manifestación de los estudiantes, gente que 
La protesta se fue apagando a partir de entonces. Sorpresivamente, sin embargo, el presidente Roca comunicó tan sólo unos días después que había decidido abandonar el proyecto de unificación de la deuda externa. El plan financiero se había vuelto "bandera ostensible de movimientos tumultuosos y hasta criminales", explicaba, y era por lo tanto irrealizable. La determinación de Roca sacudió a las filas del oficialismo. Pellegrini declaró que aquel giro constituía una "cobardía incalificable" que lo colocaba a él, comprometido desde el inicio con la tramitación del plan financiero, en "una posición falsa y ridícula". Los partidarios del senador acusaban a Roca de faltar a sus deberes al dejar sin efecto la renegociación de la deuda. Insinuaban también que se había pretendido buscar un "chivo emisario" frente a la magnitud del descontento causado por la operación. ${ }^{27} \mathrm{El}$ asunto de la unificación de la deuda se transformó, por lo tanto, en el motivo desencadenante de un grave conflicto en el interior del PAN. Si bien, como mencionamos anteriormente, la alianza política entre Roca y Pellegrini no había estado nunca exenta de tensiones, hasta ese momento ambos habían sabido manejarlas de manera de evitar una ruptura. Pero las discrepancias afloraron finalmente en julio de 1901. Volveremos sobre esta cuestión más adelante porque

pertenecía probablemente al universo de las "calles populosas" y que fluctuaba entre la participación y la simple curiosidad.

${ }^{27}$ DSCS, 25 de julio de 1901, pp. 141-142. También, Ramos, Memorias, 1939, p. 215; Ibarguren, Historia, 1969, p. 120. En solidaridad con Pellegrini se produjeron varias renuncias en el gabinete nacional, entre ellas la del ministro de Hacienda Emilio Berduc, autor formal de proyecto de unificación. tuvo importantes derivaciones. Al referirse a los acontecimientos que llevaron al fracaso de la unificación la literatura ha señalado por lo general ese aspecto. ${ }^{28} \mathrm{En}$ contraste, se ha reparado mucho menos en el sentido político contestatario que tuvo la movilización y en las formas beligerantes que exhibió. Ese es, precisamente, el punto que quiero subrayar aquí.

La prensa enemiga del gobierno fue la que instaló ese sentido político en primer término. Los diarios aseguraban que el país "se había salvado en la calle" y celebraban aquel "triunfo espléndido de la soberanía popular". ${ }^{29}$ Hemos visto que los periódicos opositores criticaron fuertemente la unificación de la deuda externa, una operación que -afirmaban- atentaba contra el honor nacional y contra la integridad del país. Por encima de ello, sin embargo, lo que resaltaban era la supuesta incapacidad de los autores de aquel arreglo para medir "la trascendencia y la responsabilidad de sus actos, en relación con

${ }^{28}$ Botana, Orden, 1994, p. 224; Gallo, Carlos, 1997, pp. 68-69; Cortés, "Auge”, 1995, p. 204, y Gerchunoff, Rocchi y Rossi, Desorden, 2008, p. 283.

${ }^{29}$ La Prensa y El Tiempo, 31 de julio de 1901; también La Nación, 5 de julio de 1901. DSCD, 8 de julio de 1901, p. 288. Los diarios opositores denunciaron luego que la declaración del estado de sitio había sido una medida "abusiva e infundada" que el gobierno tomó con el propósito de aplacar la protesta y de silenciar al periodismo. Vale la pena apuntar aquí que la prensa periódica poseía en esos años un considerable margen de maniobra en términos de garantías otorgadas a la libertad de expresión. Las medidas de censura eran excepcionales y se verificaban, en general, en circunstancias de marcada tensión política. De hecho, eso fue lo que ocurrió en julio de 1901. En el momento más álgido de la protesta se ordenó la clausura de La Nación, pero la disposición fue dejada sin efecto al día siguiente. 
la fortuna y los destinos presentes y futuros de la república". ${ }^{30}$ Y siendo así, la expresión del descontento era no sólo legítima sino, aún más, necesaria. La Prensa, especialmente, convocó a un gran movimiento de protesta que obligara al gobierno a "retroceder" en sus decisiones. Y sus exhortaciones tuvieron eco. Los estudiantes enarbolaron la consigna del patriotismo herido, pero cuando la movilización se puso en marcha el carácter político de los reclamos se fue haciendo cada vez más explícito. La solicitud firmada por los universitarios reprobaba "la voluntad sin límites del general Roca y de sus copartícipes en el gobierno [que] juegan y negocian con la opinión y el crédito". "La elección popular es un recuerdo", se quejaban los jóvenes, "digamos claramente que lo que queremos es combatir al gobierno actual". ${ }^{31}$ Ya en la calle, las acciones de los manifestantes reforzaron aún más ese significado. Los blancos que eligieron fueron políticos. Las reclamaciones por el convenio suscrito con los acreedores devinieron en mueras, insultos y hasta violentos ataques contra el presidente, el senador Pellegrini y los órganos que les respondían. Roca y Pellegrini aparecían ante la opinión pública como los artífices del acuerdo financiero, pero eran además quienes encarnaban la esencia del sistema de control político que las voces opositoras denunciaban. Los estudiantes (y los "grupos de pueblo" que se acoplaron a la protesta) fueron a buscarlos a sus casas, exigiendo a gritos la renuncia del presidente. Ante amigos y enemigos, la movilización en rechazo de la unificación de la deuda se

${ }^{30}$ La Prensa, 12 de junio de 1901.

${ }^{31}$ La Prensa, La Nación y El Tiempo, 2 de julio de 1901 . mostró como un desafío, como una "revolución sin armas” contra el gobierno de Roca. $^{32}$

\section{Los reclamos a favor de la guerra con Chile}

El sentido político impugnador que impregnó la movilización contra la unificación de la deuda persistió en el recuerdo de quienes fueron testigos de los acontecimientos de aquellos días. No faltaron, por otra parte, nuevas circunstancias en las que la dinámica opositora basada en las denuncias periodísticas se tradujo en demostraciones y protestas callejeras, a veces agresivas. La experiencia de lo ocurrido en el invierno de 1901 vino a reforzar el discurso de quienes instaban a que la "voluntad soberana del pueblo", burlada en los comicios, se pronunciara a través de otros canales más efectivos.

En diciembre de ese mismo año 1901, el diferendo limítrofe con Chile se agravó hasta el punto de que un enfrentamiento bélico parecía ahora sí próximo a estallar. En ese contexto, y con el antecedente de la cuestión de la deuda externa, se exacerbaron los clamores acerca de la soberanía nacional en peligro y los consiguientes reproches al gobierno. Esta vez el eje era la política externa, en particular la necesidad de contener el supuesto "peligro chileno”. De nuevo, el periodismo asumió la voz cantante. La Prensa, especialmente, inició una campaña exigiendo la adopción de una política de "mano firme" que permitiera frenar las presuntas aspiraciones

${ }^{32}$ La Prensa, 31 de julio de 1901. No se registraron, por ejemplo, ataques a símbolos del capital británico a pesar de que las inversiones y los préstamos extranjeros tenían primordialmente ese origen. 
expansionistas del país vecino. El diario criticaba las que consideraba defecciones del gobierno argentino. Se oponía a los acuerdos diplomáticos o los arbitrajes porque, sostenía, terminaban beneficiando las infundadas reclamaciones chilenas. Desde las páginas de La Prensa se lanzaban proclamas belicistas y se instaba a que la Argentina emprendiera una carrera armamentística que la convirtiera en la potencia política y militar de América del Sur. Pero además, de nuevo el discurso del diario iba más allá. "La paciencia del público va agotándose", advertía, "el alma popular comienza a palpitar violenta e intensamente". No podía pasar mucho tiempo antes de que la "presión del patriotismo herido" se hiciera sentir en las calles. ${ }^{33}$

La campaña montada por La Prensa incluyó el apoyo a la creación de la Liga Patriótica Argentina. El objetivo de esta agrupación era estimular a los ciudadanos para que colaboraran por diversos medios (recaudación de fondos, participación en los ejercicios defensivos, firma de solicitudes, etc.) en la defensa de los intereses nacionales. La Liga se proponía, asimismo, presionar a favor del desenvolvimiento de una política exterior agresiva. ${ }^{34} \mathrm{El}$ acto inaugural se celebró el 19 de diciembre en un teatro de la capital. Estanislao Zeballos fue el principal orador. Zeballos

${ }^{33}$ La Prensa, 2 y 4 de diciembre de 1901. La prédica belicista de La Prensa contrastaba con la posición más moderada que en esa coyuntura mostró $L a$ Nación. El diario mitrista abogaba por una estrategia de diálogo para resolver la escalada en la disputa con Chile. Esa era, de hecho, la dirección que seguía la política exterior de Roca, aunque sin abandonar por completo los preparativos para un potencial enfrentamiento armado.

${ }^{34}$ Mc Gee, Contrarrevolución, 2003, p. 49. dirigía la influyente Revista de Derecho, Historia y Letras, era redactor de La Prensa, profesor universitario y representaba, en definitiva, una voz pública destacada. Era un activo promotor de la política antichilena y nutría su prédica nacionalista de todo tipo de construcciones históricas y geopolíticas. La conferencia que pronunció en la inauguración de la Liga Patriótica fue un compendio de los argumentos que tantas veces había difundido desde las páginas de La Prensa, pero expuestos con un marcado tono dramático. Realizó primero una larga enumeración de las supuestas ofensas que Chile venía infligiendo a la Argentina desde la época colonial. Entre aclamaciones del público enardecido, formuló duras acusaciones contra el gobierno de Roca, porque lejos de practicar una política "viril y de visera alzada" se empeñaba en mantener una posición demasiado “contemplativa”. Procuró asimismo incitar al auditorio para que diera muestras de su patriotismo. Vehemente defensor de la carrera armamentística, Zeballos declaró "que si fuese necesario debemos dar nuestras economías y hasta nuestras joyas, para fomentar el poder naval que necesitamos a fin de garantizar nuestra victoria en el mar". Exponente por excelencia de la gravitación que alcanzaba un nuevo nacionalismo cultural y esencialista, proclamó el inminente arribo del día en que "se derrumbará la civilización chilena como un castillo de naipes". ${ }^{35}$

${ }^{35}$ Fragmentos del discurso reproducidos en Ferrari, Conflicto, 1968, pp. 47-48. Véase también Lacoste, Imagen, 2003, pp. 332-333. Acerca de la enunciación hacia fines del siglo XIX y comienzos del $\mathrm{xx}$ de un nacionalismo de corte cultural y esencialista, véanse Terán, Vida, 2000, pp. 57-60, y Bertoni, “1910”, 2005. 
El discurso de Zeballos creó un clima de efervescencia colectiva que rápidamente se trasladó a las calles. Al terminar la conferencia, ya de noche, el público (unos 5000 concurrentes, según informan las crónicas, entre los que había al parecer numerosos estudiantes universitarios) organizó una manifestación a la salida del teatro. Portando banderas argentinas, los manifestantes llegaron hasta la Plaza de Mayo y se congregaron para entonar el himno nacional. A continuación, y dando gritos de “ $i$ Guerra!" “ $i$ Guerra!”, la columna marchó a la casa de Roca para exigirle una respuesta.

El presidente salió a la puerta y se trepó a una silla en ademán de hablar; pero durante largo rato no pudo conseguir su objeto, porque los gritos atronadores de aquella juventud entusiasta lo hacían imposible. - Basta de arreglos y de protocolos! - ¡Basta de explicaciones y vamos de una vez a la guerra! ${ }^{36}$

Cuando finalmente pudo hacerse oír, Roca les recomendó "calma” y "circunspección", porque -dijo- "había que guardar las energías para cuando fuera necesario golpear al que nos hostiga". Antes de dispersarse, la movilización se dirigió todavía al edificio de La Prensa, en la Avenida de Mayo, y "llenó por completo el hall, lanzando vivas a la república y a la patria”. La demostración concluyó pasada la medianoche, pero se reiteraron otras similares los días siguientes. Grupos de manifestantes recorrían las calles céntricas cantando el himno y "con la cabeza descubierta". Hubo incluso algunos "exaltados" que pretendieron atacar la emba-

${ }^{36}$ La Prensa, 20 de diciembre de 1901. jada chilena, pero fueron atajados por un cordón policial. ${ }^{37}$

Mientras en las calles se sucedían las manifestaciones pro bélicas, las diplomacias de ambos países trabajaban para alcanzar un compromiso de última hora que permitiera distender la situación. El acuerdo se dio a conocer el 25 de diciembre y, de hecho, allanó el camino para una solución más definitiva que habría de lograrse al año siguiente con la firma de los llamados Pactos de Mayo. Significativamente, no obstante, lejos de aplacar la agitación callejera la noticia de la firma del arreglo indignó a los jóvenes que se lanzaron impetuosamente a protestar contra lo que consideraban un flagrante renunciamiento del gobierno argentino. Las nuevas manifestaciones derivaron en tumultos y reiterados choques de los manifestantes con la policía. Miles de personas, en su mayoría estudiantes, ocuparon las "calles centrales" dando "vivas a la República Argentina" y profiriendo "demostraciones de reprobación al gobierno". Como ya había ocurrido en días anteriores, el edificio de La Prensa se transformó en un lugar de reunión de los manifestantes que se concentraban allí para organizarse y encender los ánimos entre "fogosos discursos". Pero el hall del edificio funcionó también como refugio para los que huían de la

${ }^{37}$ La Prensa, 20 al 24 de diciembre de 1901; Caras y Caretas, 21 de diciembre de 1901. La Prensa poseía un magnífico edificio en el que además de la redacción y la imprenta funcionaban una biblioteca pública, salones de conferencia, una escuela de música, un consultorio médico gratuito y una oficina de asesoramiento jurídico. En el hall central se ubicaban varias pizarras en las que los empleados del diario escribían las últimas noticias para que el público pudiera leerlas. Saítta, Regueros, 1998, p. 31, y Marco, Historia, 2006, p. 416. 
represión policial. Los diarios reprobaron el accionar de los vigilantes que "machete en mano" arremetían contra los grupos que reclamaban en las calles. La Prensa acusó a Roca de haber incentivado en un primer momento las demostraciones que luego ordenó reprimir.

¿Por qué si se aceptaron y se solicitaron sus entusiasmos cuando el gobierno necesitaba de ellos para sentirse fuerte ante la amenaza de un conflicto armado, se los sofoca ahora en una forma tan insólita y con un rigor tan desmedido?

Formuló a propósito de ello una rimbombante advertencia que era, al mismo tiempo, una renovada invitación a la protesta:

Debe el presidente convencerse de una vez por todas de que el pueblo va perdiendo la costumbre de soportar en silencio los vejámenes que a él le plazca departirle, $\mathrm{y}$ de que es peligroso extremar ciertos procedimientos, como es imprudente jugar con armas de fuego cuando ellas están cargadas. ${ }^{38}$

El discurso periodístico insistía, por lo tanto, en difundir la imagen de un gobierno que obraba en detrimento del interés general y que erraba sus políticas ya fuera por ineptitud, por negligencia o porque sus designios eran otros: la concentración de poder y la protección de intereses particulares o "espurios", etc. Por otra parte, esa misma prédica mostraba a "la juventud estudiosa" como la contracara de los vicios que corroían a las esferas gubernamentales. Los diarios acentuaban

${ }^{38}$ La Prensa, 27 de diciembre de 1901, y Caras y Caretas, 28 de diciembre de 1901. la actitud "viril", "desinteresada" e "idealista” de los jóvenes, que se erigían en los guardianes de los sentimientos patrióticos y en los impulsores de la regeneración cívica y moral que el país demandaba. Todo indica que los estudiantes asumieron con entusiasmo ese papel que se les pretendía adjudicar. Los testimonios coinciden en señalar que "todos o casi todos los jóvenes de aquel tiempo" estaban convencidos de que "Roca era el culpable, el gran culpable, acaso el único culpable, de las calamidades que pesaban sobre este país". ${ }^{39} \mathrm{Y}$ actuaban en consecuencia.

Las denuncias periodísticas continuaron acumulándose durante el resto del gobierno de Roca. Las acusaciones sobre autoritarismo y arbitrariedades se hicieron cada vez más fuertes contribuyendo a la lenta pero persistente labor de deslegitimación política que llevaban adelante los diarios opositores. Los ataques de la prensa arreciaron en el último tramo de la presidencia de Roca, a propósito de la definición de quien habría de sucederlo al finalizar su mandato en 1904 . Se propagó entonces la idea de que Roca buscaba imponer a su sucesor y crecieron las apelaciones a favor de "una vigorosa protesta cívica" que impidiera aquella nueva afrenta contra los derechos del pueblo.

\section{Las demostraciones contra la Convención de Notables}

El régimen conservador tenía uno de sus pilares en el control de la sucesión presidencial. El candidato del PAN surgía de negociaciones y acuerdos que se tejían dentro de la elite gobernante. Luego los

39 Vedia, Como, 1954, p. 41. 
manejos electorales garantizaban el triunfo de esa candidatura. La definición de la fórmula oficial poseía, por lo tanto, una relevancia indudable para la vida política nacional. Pero no era esa una instancia exenta de conflictos. Por el contrario, solían emerger pugnas y resistencias que complicaban la designación de una candidatura consensuada. Roca había logrado sortear esas resistencias en 1898, pero el factor determinante había sido en aquella oportunidad el apoyo de Pellegrini. La situación era muy distinta cinco años después. La enemistad surgida entre los antiguos socios había causado una profunda división en el seno del partido gobernante. Pellegrini se había distanciado del roquismo y no ocultaba sus aspiraciones presidenciales. Fue en ese contexto que surgió la idea de reunir una convención del PAN para definir al candidato que habría de suceder a Roca en 1904. La intención era eludir una contienda abierta y los riesgos que ello podía entrañar para la unidad del partido. Pero la llamada Convención de Notables se convirtió también en el ámbito dentro del cual Roca pudo maniobrar de tal modo de frustrar las pretensiones de su ex aliado. A través de enredadas transacciones logró pactar con otras facciones del partido un candidato alternativo, Manuel Quintana, que aparecía como un "independiente". Pellegrini perdía así, una vez más, la posibilidad de llegar a la presidencia del país. En medio de fuertes denuncias de coacciones e imposiciones del roquismo, anunció su decisión de no participar de la convención. ${ }^{40}$

Todos estos movimientos que se producían alrededor de la definición de la

${ }^{40}$ Botana, Orden, 1994, pp. 225-226, y Gallo, Carlos, 1997, p. 69. candidatura presidencial dieron lugar a duras críticas de la prensa opositora. Los diarios desestimaron rápidamente la relevancia de las disputas entre roquistas y pellegrinistas para concentrarse, en cambio, en el "audaz atentado contra la soberanía popular" que, afirmaban, se pretendía perpetrar. El "engendro" de la Convención de Notables, explicaban, era un nuevo ardid preparado por la "casta gobernante" para delegarse el mando "en una sucesión sin término". Unos cuantos "saltimbanquis políticos" habrían de congregarse para ratificar "el juego electoral del único que allí piensa y quiere: el presidente de la república". La voluntad presidencial, repetían los diarios, se hallaba "en la plenitud de su imperio", Roca se disponía a digitar la elección de su sucesor. ${ }^{41}$ En realidad, la necesidad en la que se encontró Roca de negociar una candidatura de compromiso para frenar las aspiraciones de Pellegrini no hacía más que evidenciar la declinación de su influencia dentro del Pan, pero esos matices se perdían entre las encendidas argumentaciones que día a día desplegaban los editoriales periodísticos. El eje de esas argumentaciones era el atentado que el "oficialismo impúdico" proyectaba consumar en perjuicio de la voluntad popular al impedir que fuera su veredicto, libremente expresado en las urnas, el que decidiera sobre la elección presidencial. La cruzada del periodismo contra la asamblea del PAN ocupó semanas enteras hasta que, por último, el día anterior a que se iniciaran las deliberaciones, La Prensa dio el paso decisivo e hizo un llamamiento explícito para "que conste en las calles públicas la verdad de

${ }^{41}$ Véase La Prensa, La Nación y El Tiempo, 9 al 12 de octubre de 1903. 
la protesta que la parodia de la convención electoral inspira al país". ${ }^{42}$

Para entonces ya estaba en marcha la organización de una "protesta de la juventud" en repudio de la Convención de Notables. Estudiantes de la Facultad de Derecho habían emprendido un movimiento para reclamarle al presidente Roca que "en nombre de las conveniencias públicas y de nuestra democracia, desista del propósito de querer erigirse en mentor del pueblo". Las declaraciones de los estudiantes reiteraban el tono y el contenido de las acusaciones periodísticas. Denunciaban una "conspiración liberticida, fraguada entre las sombras palaciegas", e instaban a los ciudadanos a no tolerar

que se erijan en sus tutores y en árbitros supremos de sus destinos, los mismos a quienes la opinión independiente y sana del país entero, indica como autores de la ruina de sus finanzas y de la corrupción de sus instituciones. ${ }^{43}$

La Convención de Notables debía sesionar el lunes 12 de octubre. Los días previos los estudiantes se mostraron muy activos. Publicaron en los principales diarios de la ciudad un manifiesto en el que reiteraban las imputaciones contra los "delincuentes de la política argentina". Informaron, asimismo, la realización de un mitin que habría de atestiguar el rechazo provocado por "tanto escarnio". ${ }^{4}$

${ }^{42}$ La Prensa, 11 de octubre de 1903.

${ }^{43}$ Los estudiantes iniciaron los trabajos de organización en el mes de julio. Véase, por ejemplo, $L a$ Prensa, 21 y 24 de julio de 1903, p. 8; La Nación, 24 de julio de 1903, y Caras y Caretas, 8 de agosto de 1903.

${ }^{44}$ La Prensa, 9 de octubre de 1903, y La Nación, 11 de octubre de 1903.
La demostración se efectuó el domingo 11. "Miles de jóvenes entusiastas" marcharon por el centro de la ciudad dando "gritos hostiles a la convención y al régimen actual". Tuvo que interponerse la policía para dispersar a los manifestantes que apedrearon la casa de Roca y la imprenta del diario El País. A la madrugada, había todavía algunos grupos que rondaban los hoteles donde se suponía que estaban alojados los convencionales llegados de las provincias. Nuevamente fue necesaria la intervención policial para disolverlos. ${ }^{45}$

Al día siguiente, la policía montó un importante operativo previniendo nuevos disturbios que dificultaran la realización de la Convención. Una "enorme concurrencia” había comenzado a congregarse desde temprano en las cercanías del salón donde se iba a efectuar la reunión, pero la calle estaba cerrada al tránsito, por lo que tuvieron que conformarse con "prodigar grandes silbatinas cada vez que se cercioraba de la llegada de un convencional". Las protestas recrudecieron cuando, ya por la tarde, se supo que Manuel Quintana había sido efectivamente proclamado candidato del PAN para los comicios presidenciales. "Al enterarse el público del resultado, se armó la más descomunal de las algarabías, con gritos, silbidos y ¡mueras! y ¡abajos! que era un contento." 46 Se inició entonces la represión policial. Las fuerzas del Escuadrón de Seguridad arremetieron "sable en mano" contra la mul-

${ }^{45}$ La Prensa, La Nación y El País, 12 de octubre de 1903, y Caras y Caretas, 17 de octubre de 1903. El País, originalmente pellegrinista, había quedado en manos de grupos afines al roquismo luego del conflicto entre los dos líderes del PAN.

${ }^{46}$ Caras y Caretas, 17 de octubre de 1903. 
titud. Los manifestantes resistían con piedras y bastones, al grito de "no queremos tutores". Hubo incluso disparos desde ambos lados. Grupos entre los que, según las crónicas, predominaba "el elemento juvenil" intentaron marchar una vez más hacia la casa del presidente Roca y luego a la del flamante candidato, Manuel Quintana, pero la policía se los impidió. Las últimas corridas se registraron ya por la noche cuando algunos jóvenes que continuaban deambulando por las calles del centro se toparon con un grupo de convencionales a los que persiguieron, insultándolos, unas cuantas cuadras. Los disturbios habían dejado numerosos lesionados y heridos, así como una considerable cantidad de detenidos. ${ }^{47}$

La Convención de Notables había sesionado, mientras en las calles se producían choques entre los manifestantes y las fuerzas de seguridad. Al final de aquella jornada, lo que quedaba era la sensación - construida y difundida por la prensade que se había producido una agraviante usurpación de la soberanía popular, consumada a través de la designación (que luego el fraude simplemente habría de ratificar) del candidato "ungido" para suceder a Roca en la presidencia de la república. Los diarios se esforzaban por apuntalar la imagen de un triunfo simbólico que las manifestaciones supuestamente habían conquistado. El PAN había logrado concretar aquel "acto prohibido por la opinión" que, aseguraban, era la Convención de Notables. Pero eso sólo había sido posi-

${ }^{47}$ El Tiempo, 12 de octubre de 1903; La Prensa, La Nación, El País y Tribuna, 13 de octubre de 1903. Puede verse la versión policial de los hechos en AP, CN, sección $1^{a}$, libro 136, 12 de octubre de 1903 , f. 289. ble al precio de una "brutal" represión policial. La "conducta agresiva y terrorista" que habían exhibido las fuerzas de seguridad era un mal síntoma, aseguraba La Prensa. Daba cuenta del exasperado afán del gobierno por acallar "las asambleas populares y políticas que se inician contra el actual estado de cosas". ${ }^{48}$

Circuló con insistencia el recuerdo de lo que había sucedido dos años atrás, en julio de 1901. La prensa adversa al gobierno se ocupó de invocar aquel recuerdo con el propósito de actualizar la idea de que la población estaba "templada" para producir "grandes explosiones populares, que hacen época y causan escarmiento":

Recuérdese cómo murió el proyecto de unificación de los empréstitos exteriores, náufrago devorado por una grandiosa borrasca popular. ¿Por qué el proceso deprimente de las candidaturas no habría de desprender, como solución final, una conmoción cívica imponente de ese género? ${ }^{49}$

Afirmaciones de ese género alimentaban las acusaciones acerca de campañas desestabilizadoras orquestadas para crear "un clima de sedición y encono contra la autoridad". Tribuna, el órgano del roquismo, advertía que la protesta "ha sido y será siempre fuente de toda clase de perturbaciones y conflictos". Escenas como las que se habían vivido en la ciudad durante esos días "desdicen nuestra cultura y civilización". ${ }^{50}$ Lo que se estaba dis-

${ }^{48}$ La Prensa, 14 y 17 de octubre de 1903.

${ }^{49}$ La Prensa, 4 de junio de 1903.

${ }^{50}$ Tribuna, 13 y 19 de octubre de 1903 . Se buscaba remarcar el supuesto contraste entre la modernidad de Buenos Aires (la capital del país, su vidriera frente al mundo) y la "barbarie" que se adueñaba de 
cutiendo era, en definitiva, la validez del uso político de la calle, la legitimidad del derecho de protesta. Civilización y protesta no eran términos antagónicos en el marco del discurso opositor al régimen. El fraude y la pretensión del PAN de monopolizar el poder desmentían, según esto, el carácter civilizado de la política y constituían -en palabras de La Prensa - una "audacia provocativa de las iras de la opinión". La protesta, incluso si tomaba formas violentas, aparecía en ese contexto como plenamente legítima. En las notas críticas que habían publicado los diarios (así como también en las acciones que luego desplegaron los manifestantes) las alternativas que habían rodeado la designación del candidato presidencial del PAN no eran sino una muestra más de los mecanismos a través de los cuales el régimen se reproducía sin habilitar la rotación del poder. Las manifestaciones no habían podido impedir la usurpación de la soberanía popular tantas veces denunciada, pero habían servido - desde esa perspectiva- para exponer en toda su crudeza la arbitrariedad del dominio del PAN. Aquel era, sentenciaba La Nación, el "triste y funesto epílogo" de la presidencia de Roca. ${ }^{51}$

\section{CONCLUSIONES: UN ORDEN INSEGURO}

Como todo hacía suponer, la candidatura de Manuel Quintana fue la vencedora en las elecciones nacionales que se llevaron a cabo el 10 de abril de 1904. A primera vista, la "máquina roquista" parecía haber triunfado. Sin embargo, era un triunfo que

las calles cuando se transformaban en el escenario de manifestaciones de protesta.

${ }^{51}$ La Nación, 10 de octubre de 1903. pronto se iba a revelar bastante endeble. Quienes desde dentro del régimen pugnaban por una progresiva democratización del mismo ganaron a partir de entonces cada vez más influencia. Se había ido arraigando en un sector de la elite gobernante la convicción de que se requería poner unos usos políticos atrasados y unas prácticas electorales falseadas a la altura no sólo de los preceptos constitucionales, sino también de los logros económicos y sociales que Argentina había conquistado desde 1880. Se desenvolvió a partir de entonces el ciclo de reforma, transformación y finalmente derrota del régimen conservador. Como se señaló al comienzo de este trabajo, la reforma electoral aprobada en 1912 modificó las reglas del juego, habilitando una inesperada victoria de la oposición en los comicios presidenciales de 1916. Ese recorrido es el que la historiografía ha considerado tradicionalmente. Se ha observado la puesta en marcha de un sistema de hegemonía gubernamental por parte del PAN y luego la estrategia implementada para producir una apertura gradual y controlada. La mirada que hemos denominado clásica sostiene que fueron sobre todo las contradicciones internas del régimen las que empujaron la transformación. La oposición política presionó desde afuera, pero sin poder reiterar la amenaza que en su momento habían introducido el alzamiento armado del Noventa y sus secuelas. Paradójicamente, no fueron las armas sino los votos los que en 1916, en el contexto de unas votaciones saneadas por la reforma electoral, le permitieron a la UCR el acceso al poder. ${ }^{52}$

52 Luego del ostracismo en el que estuvo sumergida desde fines de la década de 1890, la UCR se reorganizó bajo el liderazgo de Hipólito Yrigoyen y 
El planteamiento que he procurado exponer aquí, basándome en las líneas abiertas por una renovación historiográfica que, aunque con vaivenes, ha avanzado en los últimos años y en los resultados de mi propia investigación, apunta a introducir matices en la interpretación establecida y propone nuevas perspectivas de análisis que contribuyan a complejizar la visión que se tiene sobre la política en tiempos del orden conservador. La intención ha sido explorar una serie de cuestionamientos y protestas que si bien no asumieron el carácter de revoluciones o desafíos de gran amplitud y trascendencia, fueron no obstante profundizando las grietas que socavaban la legitimidad del régimen. La figura de Julio A. Roca se convirtió en el blanco principal de esos cuestionamientos porque se hallaba indisolublemente identificada con el exclusivismo político que ejercía el PAN. Desde ese punto de vista, la transformación que el régimen experimentó desde adentro, animada por una facción reformista de la propia elite gobernante, es inseparable del proceso de deslegitimación que paralelamente se fue desarrollando en otros escenarios y mediante la intervención de otros actores. En este artículo nos hemos concentrado en describir una dinámica opositora que se articulaba a través de la prensa y que se exteriorizaba en las manifestaciones callejeras protagonizadas por los estudiantes universitarios.

La prensa poseía una notable capacidad de implicarse políticamente con su prédica y de persuadir al público con sus

regresó a la escena política en 1903. Los radicales intentaron una nueva y fallida rebelión armada en 1905. En 1916 Yrigoyen se convirtió en presidente de la república. apelaciones. La modernización periodística que los diarios transitaban a principios del siglo Xx no aparecía como un obstáculo que los inhibiera de participar en el debate político como formadores y movilizadores de la opinión pública. La independencia que los diarios reivindicaban no significaba prescindencia respecto de los acontecimientos políticos, sino la ausencia de lazos que los ataran al poder y les imposibilitaran realizar la crítica sistemática, virulenta, del proceder gubernamental. De esa manera, aquellos periódicos que lideraban la transición hacia las formas más modernas del periodismo, podían ser igualmente opositores acérrimos del gobierno y convertirse en actores fundamentales de la escena política. El ejemplo de La Prensa resulta paradigmático en ese sentido. ${ }^{53}$ Pero además, las denuncias periodísticas encontraron en la intervención de los estudiantes universitarios la posibilidad de ser traducidas al lenguaje de la movilización callejera. Se requiere seguir indagando sobre la relación que tenían los jóvenes con los diarios a comienzos del novecientos. Es posible intuir que era una vinculación estrecha. Los universitarios cumplieron un papel destacado en la articulación entre las críticas de la prensa opositora y la dinámica de protesta que se desplegaba en las calles de Buenos Aires. Un testigo de las manifestaciones de julio de 1901 en rechazo a la unificación de la deuda ex-

53 La literatura ha tendido a plantear una contradicción entre la modernización periodística y la pervivencia de un modo de intervención política supuestamente "faccioso" y anacrónico. Véase Saítta, Regueros, 1998, p. 30. Por el contrario, aquí defendemos la importancia de pensar en una prensa que era moderna $y$ política a la vez. 
terna afirmó en aquel momento que fueron los estudiantes quienes "llevaron los debates a la calle". ${ }^{54}$

El hecho es, por lo tanto, que en el contexto de un gobierno aparentemente fuerte y defensor de la doctrina del orden público, como era el de Julio A. Roca, pudo gestarse y desarrollarse una dinámica contestataria basada en las incitaciones de la prensa y en la práctica del uso de la calle para la protesta. Más aún, en un escenario dominado por el PAN y por su pretensión de acaparar el poder, en ausencia de otros partidos organizados y capaces de asumir un papel protagónico, fueron los diarios los que se abocaron a la tarea de establecer la intensidad, los temas y muchas veces las modalidades de la actividad política opositora. ${ }^{55}$ Ciertamente, esa actividad no alcanzó a conmover en ningún momento la estabilidad del régimen político, pero en contrapartida no parece desacertado concluir que ayudó a que progresivamente se instalara la convicción de que el fraude, los comicios manipulados y otros controles, lejos de garantizar el orden, estimulaban las actitudes tumultuosas de los disidentes. Cuando Carlos Pellegrini rompió

${ }^{54}$ Ramos, Memorias, 1939, p. 212. Los estudiantes acudían con asiduidad a las redacciones de los periódicos, y en el caso de La Prensa, especialmente, hacían un uso frecuente de las instalaciones del diario. Durante la huelga de 1904 en la Facultad de Derecho, por ejemplo, se reunieron en más de una oportunidad en los salones del edificio para celebrar allí sus asambleas. Véase La Prensa, 16 de septiembre de 1904.

${ }^{55}$ En ese sentido, resultan por demás sugerentes las reflexiones que respecto de otro escenario (el de la ciudad de México durante los años del gobierno maderista) propuso Ariel Rodríguez Kuri para analizar la conducta opositora que en ese marco siguió el diario El Imparcial. Véase Rodríguez, "Discurso", 1991. con Roca, y después de ver frustradas sus ambiciones presidenciales en 1903, se alejó del PAN y dedicó gran parte de sus esfuerzos a promover una reforma que eliminara el fraude para impedir de esa manera que las oposiciones se vieran arrastradas a tomar formas sediciosas y violentas. Pellegrini se convirtió, a partir de entonces (y hasta su muerte en 1906), en uno de los principales impulsores de la causa de la reforma. Los sucesos de julio de 1901, las formas y los sentidos que había revestido la protesta contra la unificación, habían intensificado en él esa preocupación.

Es necesario enseñar a la juventud que no combaten ideas rompiendo a pedradas los vidrios de una imprenta, ni insultando impunemente a la autoridad y a los adversarios, que su acción no es digna en esa forma, en esos lugares, sino en los atrios, yendo a votar para hacer triunfar sus opiniones por medio de la única arma legal del ciudadano. ${ }^{56}$

Para ello se requería, Pellegrini lo sabía y lo expresó cada vez con más contundencia, depurar unos comicios siempre sospechados.

Sostengo, en definitiva, que la dinámica beligerantemente opositora que, en torno a los diarios y en el espacio político de las calles de la ciudad, se plasmó hacia principios del novecientos en Buenos Aires alimentó la percepción de un orden que, como bien expresó Natalio Botana, era ambivalente: "duradero sin por ello dejar de ser inseguro para quienes ejercían el control". ${ }^{57}$ En los años siguientes

${ }^{56}$ DSCS, 25 de julio de 1901, p. 143, y Gallo, Carlos, 1997, pp. 27-32.

${ }^{57}$ Botana, Orden, 1994, p. XXIII. 
las representaciones sobre la protesta callejera iban a sufrir cambios significativos. Los discursos elogiosos de la "algazara del pueblo en la calle" dejaron paso a otras miradas más aprensivas. El impacto de la conflictividad social y obrera en una ciudad que crecía y se modernizaba llevó al esfuerzo oficial por regular la ocupación del espacio público por parte de los grupos contestatarios. ${ }^{58}$ Esas inquietudes, y las que traía consigo la contemplación del fenómeno de las "multitudes urbanas", se agudizaron hacia el Centenario, en 1910. Entre tanto, sin embargo, el uso de la calle para la participación política se convirtió en un camino transitado por quienes buscaban influir en las decisiones de los gobernantes o repudiar lo que consideraban actos despóticos de unas autoridades corruptas.

El interés por reconstruir estas formas de acción política y de protesta popular se inscribe en el marco del esfuerzo por descomponer una visión según la cual durante esos años el proceso político estuvo dominado por la dinámica interna del régimen, mientras que la población supuestamente permanecía atrapada en la disyuntiva entre la pasiva subordinación al orden impuesto y la resistencia violenta que surgía bajo la forma de la insurrección armada. La intención no es componer una imagen opuesta a la de la hegemonía gubernamental, que ignore o niegue los límites que la misma imponía a la par-

${ }^{58}$ En ese nuevo contexto se profundizó asimismo el debate sobre los alcances de la libertad de prensa, en la medida en que los periódicos anarquistas (y en menor medida socialistas) fueron percibidos como promotores de la protesta. Véase Suriano, Anarquistas, 2001, pp. 182 y 183; también Yablón, "Patronage", 2003, p. 222. ticipación política popular. Lo que defiendo, en lugar de ello, es la relevancia de un punto de vista que muestre la variedad de modalidades, espacios y protagonistas de la vida política tal como esta funcionaba en el contexto de los controles y de las reglas del juego vigentes. Ese enfoque puede ayudar, confío, a una mejor comprensión del proceso de construcción y legitimación (o no) del poder político durante el periodo del orden conservador.

\section{FUENTES CONSULTADAS}

Archivos

AP, CN Archivo Policial, Copiadores de notas, Buenos Aires, Argentina.

UTDT, MRNA Universidad Torcuato Di Tella, Microcopies of Records in the $\mathrm{Na}$ cional Archive, Colección Carlos Escudé, Buenos Aires, Argentina.

\section{Hemerografía}

BORA. Boletín Oficial de la República Argentina. Caras y Caretas.

DSCD. Congreso Nacional, Diario de Sesiones de la Cámara de Diputados.

DSCS. Congreso Nacional, Diario de Sesiones de la Cámara de Senadores.

El Diario.

El País.

El Tiempo.

La Nación.

La Prensa.

The Buenos Aires Herald.

The Review of the River Plate.

Tribuna. 


\section{Bibliografía}

-Alonso, Paula, "En la primavera de la historia'. El discurso político del roquismo de la década del ochenta a través de su prensa”, Boletín del Instituto de Historia Argentina y Americana "Dr. E. Ravignani", núm. 15, 1997, Buenos Aires, pp. 35-70.

, "La reciente historia política de la Argentina del ochenta al centenario", Anuario IEHS, núm. 13, 1998, Tandil, pp. 393-418.

, Entre la revolución y las urnas. Los orígenes de la Unión Cívica Radical y la política argentina en los años '90, Sudamericana, Buenos Aires, 2000.

, Jardines secretos, legitimaciones públicas, EDHASA, Buenos Aires, 2010.

-Arrom, Silvia y Sevando Ortoll (eds.), Riots in the Cities. Popular Politics and the Urban Poor in Latin America, 1765-1910, Scholary Resources, Wilmington, Del., 1996.

-Bertoni, Lilia Ana, "1910 y la emergencia de 'otra' nación” en José Nun (comp.), Debates de Mayo. Nación, cultura y política, Gedisa, Buenos Aires, 2005.

-Botana, Natalio, El orden conservador. La politica argentina entre 1880-1916, Sudamericana, Buenos Aires, 1994.

"El arco republicano del Primer

Centenario: regeneracionistas y reformistas, 1910-1930" en José Nun (comp.), Debates de Mayo. Nación, cultura y política, Gedisa, Buenos Aires, 2005.

-Buchbinder, Pablo, Historia de las universidades argentinas, Sudamericana, Buenos Aires, 2005.

-Carvalho, José Murilo de, Os bestializados. $O$ Rio de Janeiro e a República que não foi, Companhia das Letras, São Paulo, 1989.

-Cibotti, Ema, "Sufragio, prensa y opinión pública: las elecciones municipales de 1883 en Buenos Aires" en Antonio Annino (coord.), Historia de las elecciones en Iberoamérica, siglo XIX, FCE, Buenos Aires, 1995, pp. 143-176.
-Connaughton, Brian F. (coord.), Poder y legitimidad en México en el siglo XIX. Instituciones y cultura política, UAM-Iztapalapa/Porrúa, México, 2003.

-Cortés Conde, Roberto, "Auge de la economía exportadora y vicisitudes del régimen conservador (1890-1916)" en Ezequiel Gallo y R. Cortés Conde, Argentina. La república conservadora, Paidós, Buenos Aires, 1995.

-Ferrari, Gustavo, Conflicto y paz con Chile (1898-1903), EudeBA, Buenos Aires, 1968.

-Gallo, Ezequiel, "El roquismo", Todo es Historia, núm. 100, 1975, Buenos Aires, pp. 14-29. , Carlos Pellegrini. Orden y reforma, FCE, Buenos Aires, 1997. , "La consolidación del Estado y la reforma política (1880-1914)" en Nueva bistoria de la nación Argentina, ANH/Planeta, Buenos Aires, 2000, t. IV, pp. 511-541.

-Gerchunoff, Pablo, Fernando Rocchi y Gastón Rossi, Desorden y progreso. Las crisis económicas en Argentina 1870-1905, EDHASA, Buenos Aires, 2008.

-Gutiérrez, Florencia, El mundo del trabajo y el poder político. Integración, consenso y resistencia en la ciudad de México a fines del siglo XIX, El Colegio de México, México, en prensa.

-Halperín Donghi, Tulio, Historia de la Universidad de Buenos Aires, EudebA, Buenos Aires, 1962.

-Ibarguren, Carlos, La historia que he vivido, EudebA, Buenos Aires, 1969.

-Lacoste, Pablo, La imagen del otro en las relaciones de la Argentina y Chile (1534-2000), FCE, Buenos Aires, 2003.

-Marco, Miguel de, Historia del periodismo argentino. Desde los orígenes hasta el Centenario de Mayo, Universidad Católica Argentina, Buenos Aires, 2006.

-Mc Gee Deutsch, Sandra, Contrarrevolución en la Argentina, 1900-1932. La Liga Patriótica Argentina, Universidad Nacional de Quilmes, Buenos Aires, 2003. 
-Pamplona, Marco, Riots, Republicanism, and Citizenship. New York City and Rio de Janeiro City during the Consolidation of the Republican Order, Garland, Nueva York, 1996.

-Peck, Donald, "Las presidencias de Manuel Quintana y José Figueroa Alcorta, 1904-1910” en Gustavo Ferrari y Ezequiel Gallo (comp.), La Argentina del ochenta al centenario, Sudamericana, Buenos Aires, 1980, pp. 309-333.

-Ramos, Julio, Desencuentros de la modernidad en América Latina. Literatura y política en el siglo XIX, FCE, México, 2003.

-Ramos Mexía, Ezequiel, Mis memorias 1853-1935, La Facultad, Buenos Aires, 1939.

-Rock, David, La construcción del Estado y los movimientos políticos en la Argentina, 1860-1916, Prometeo, Buenos Aires, 2006.

-Rodríguez Kuri, Ariel, "El discurso del miedo: El Imparcial y Francisco I. Madero”, Historia Mexicana, vol. XL, núm. 4, 1991, México, pp. 697-740.

-Ronzón, José y Carmen Valdéz (coords.), Formas de descontento y movimientos sociales, siglos XIX y XX, UAM-Azcapotzalco, México, 2005.

-Sabato, Hilda, La política en las calles. Entre el voto y la movilización. Buenos Aires, 1862-1880, Sudamericana, Buenos Aires, 1998.

, "La política argentina en el siglo XIX: notas sobre una historia renovada", en Guillermo Palacios (coord.), Ensayos sobre la nueva historia política de América Latina, siglo XIX, El Colegio de México, México, 2007, pp. 83-93.

, "El pueblo 'uno e indivisible'. Prácticas políticas del liberalismo porteño" en Lilia
Ana Bertoni y Luciano de Privitellio (comps.), Conflictos en democracia. La vida política argentina entre dos siglos, Siglo XXI, Buenos Aires, 2009, pp. 25-44.

-Saítta, Sylvia, Regueros de tinta. El diario Crítica en la década de 1920, Sudamericana, Buenos Aires, 1998.

-Suriano, Juan, Anarquistas. Cultura y politica libertaria en Buenos Aires, 1890-1910, Manantial, Buenos Aires, 2001.

-Tato, María Inés, "La contienda europea en las calles porteñas. Manifestaciones cívicas y pasiones nacionales en torno de la primera guerra mundial" en María Inés Tato y Martín O. Castro (comps.), Del Centenario al peronismo. Dimensiones de la vida política argentina, Imago Mundi, Buenos Aires, 2010, pp. 33-63.

-Terán, Óscar, Vida intelectual en el Buenos Aires fin-de-siglo (1880-1910). Derivas de la "cultura científica", FCE, Buenos Aires, 2000.

-Vedia, Joaquín de, Como los vi yo, Gleizer, Buenos Aires, 1954.

-Yablon, Ariel, "Patronage, Corruption, and Political Culture in Buenos Aires, Argentina, 1880-1916", tesis de doctorado, University of Illinois, Urbana-Champaign, 2003.

-Zimmermann, Eduardo, "La prensa y la oposición política en la Argentina de comienzos de siglo. El caso de La Nación y el Partido Republicano”, Estudios Sociales, núm. 15, 1998, Santa Fe, pp. 45-70. 